\title{
William A. Jackson: Economics, culture and social theory
}

\author{
Edward Elgar, Cheltenham, 2009, ISBN-10: 1845427106
}

\author{
John B. Davis
}

Published online: 5 June 2010

(C) The Author(s) 2010. This article is published with open access at Springerlink.com

William Jackson makes a strong and compelling case that contemporary economics, including orthodox and even heterodox (though less so) approaches, mistakenly excludes any significant thinking about the role and nature of culture in explanations of economic life. His book does two main related things: It offers a cultural critique of economics and the history that produced it; and he then uses this critique to map out a more interpretive approach to economic life. The role that meaning plays in economic behavior is emphasised - a view that would end economics' long-held commitment to emulating the natural sciences. The book also advances an understanding of social theory, explained in terms of social structure and agency, as a basis for an alternative economics that would both give space to interpretive methods and, in principle, make it possible to reformulate the main concepts of economics. This is a far-reaching book with considerable theoretical depth, coverage of the history of ideas in economics and social science, and genuine insight into how we ought to think about the social world. It is also a very timely book, given that the most sophisticated economic models of the world economypremised on a mechanistic vision of markets-failed to predict, and still cannot explain, the recent crisis and turmoil in the world economy.

The book is divided into four parts. The introduction begins by locating the aversion to, and shunning of, the idea of culture in the attraction that the seventeenth- and eighteenth-century Enlightenment methods of rationalism and empiricism came to have for social science. The idea that one can model human society on the natural world is, for Jackson, the cardinal sin from which many of the shortcomings of modern social science stem. Central to this is the conception of

\footnotetext{
J. B. Davis $(\bowtie)$

University of Amsterdam, Amsterdam, The Netherlands

e-mail: john.davis@marquette.edu

J. B. Davis

Marquette University, Milwaukee, WI, USA
} 
individual behavior as universally instrumentally rational-a conception that entitles one to dispense with any attention to social and historical context. The irony of the Enlightenment vision of course is that its critique of religion and associated rejection of supernatural argument relocated the logic of transcendence in the idea of natural law. In the case of economics, which was built around this vision, we never talk about real, socially embedded individuals, but rather only about an imaginary, lesser Robinson Crusoe deity, a universal every-man and no-man at the same time.

If we are to start over, where does Jackson have us begin? His second chapter addresses the meaning and definition of culture. Here, he summarizes the history of how the concept of culture has changed and evolved. He argues in favor of a conception of culture as a process, but sees the ever-present pull of natural science as continually posing an outcome or end-state, static conception of culture as a settled way of life. This then introduces the argument in the four chapters of Part II of the book that give a cultural critique of the history of economics from 1800 to the present.

Economics' self-image was largely constructed in classical economics by Smith, Ricardo, and Malthus, who had Enlightenment ideas about scientific progress in the beginnings of British industrialization. Their antithesis was the Romantic critique of capitalism of Coleridge, Carlyle, and Ruskin in Britain, then a continental Romanticism and the utopian and Marxian critiques of classical economics. These critiques were all broadly historicist but did not succeed in redirecting economics. By the end of the nineteenth century, the emergence of a highly individualist neoclassical economics even less receptive to the concept of culture was evident. Heterodox economic approaches also began to emerge with the rise of neoclassicism-Marxian economics, institutionalism, and Austrian economics-but for Jackson their embrace of the concept of culture has been hesitant and often confused by natural science ideals. With economics thus largely locked into a universalist and positivist orthodoxy, it fell to other social sciences-sociology, anthropology, psychology, and history-to address culture. In the postwar period of 1950 to the present, this legacy is reinforced by the increasing mathematization of economics such that most contemporary orthodox economists are unable even to conceive of the role culture plays in economic life. At the same time, heterodox economists in the postwar period, with a few exceptions, have made little use of the concept of culture-sometimes taking positions inimical to it. A small revival comes after 1960 from developments in economic methodology drawing on the philosophy of Popper, Kuhn, Lakatos, and Feyerabend from New Left thought and from postmodernism, but these have failed to have any significant impact on economics.

Jackson nonetheless tallies up the cultural critique of economics, and the list of arguments he makes is long (83-88). Economics cannot explain culture as a process; it does not recognize that explanations should be relative to local circumstances; it is not realistic; its model of behavior is perfectionist; human subjectivity and creativity are ignored; the ways in which our understanding of the world is socially constructed are overlooked; it employs reductionist explanations of individual agents and social structures; it employs a flat rather than layered view of social reality; it lacks a concept of emergence; it is mechanistic; it does not grasp 
that much of the world involves symbolism; it has a narrow concept of power and authority; it has no evolutionary or historical view of the world; it does not understand the role that interpretive methods play; it is non-pluralist with respect to method and theory; and it has a false view of the boundaries of its subject matter. This is a remarkably comprehensive and damning case-one that leaves the reader either despairing of the future of economics as a social science or seeking new foundations for it. Jackson takes the second route in Part III, 'Implications of the Cultural Critique,' to lay out in five theoretical chapters what a culturally informed economics should involve. In each case, he seeks to disabuse us of popular misconceptions about cultural thinking, which he believes have been a barrier to developing a new economics.

The first issue is relativism and realism. The misconception is that any attention to the relativity of local circumstance is tantamount to an 'anything goes' relativism, which implies that a culturally informed economics is anti-realistic. But, Jackson argues, there are different types of relativity, and "To be ontologically or epistemologically relativist goes beyond what is necessary for a cultural approach" (98), and is not required in order to give attention to the sort of spatial and temporal relativisms that cultural methods imply. Indeed, in his view, cultural thinkers are usually realists.

The second issue is the idealism and materialism dichotomy. Orthodox economics is said to be materialist in that it accords no important capacity for ideal factors to change material ones. I think this picture may be too strongly drawn, but Jackson's main argument for a 'cultural materialism' has plausibility. It is the idea that "culture can influence the material world" while at the same time "cultures would not exist without material nature" (118). This provides a way of thinking about the real effects of culture combined with an understanding of its material foundations. It also opens up space for thinking about the idea of emergent phenomena.

Jackson's third issue is that of agency and structure, referred to above in connection with advancing a new program for social theory. One consequence of orthodox economics' commitment to individualism, Jackson argues, is that social structure then became the special responsibility of sociology. But this dualism in social science left us with an impoverished theorizing about social life that might begin to be overcome if we were to understand culture as a process and acknowledge that "Culture is the bond between agency and structure" (132). Social theory would then be non-reductionist and offer a "stratified perspective [that] allows higher levels to possess powers emergent from lower levels but not wholly reducible to them" (137).

The fourth issue is interpretive methods, including hermeneutics and semiotics. Once we accept the need to think beyond traditional empiricism and rationalism, we realize that explanation always involves interpretation and is thus accompanied by prior beliefs. Rational economic man then becomes a prescriptive ideal, and orthodox economics runs the risk of merely becoming an expression of prevailing beliefs. Jackson argues that there is some progress in adopting interpretive methods in heterodox economics, which is generally supportive of pluralism, and in some 
cases attentive to the role beliefs play in economic behavior, but even here, a fuller grasp of hermeneutical thinking remains largely implicit.

The fifth issue is evolution, specifically a social and economic evolution that goes beyond narrower biological theories of evolution that reflect Darwinian-type views. Jackson's argument is that a cultural approach to economics, that is, one in which culture is defined as a process requires an evolutionary or developmental view of the world. An evolutionary perspective also fits naturally with a dynamic understanding of structure-agency thinking. In this case, moreover, there is some good news from economics, though mostly heterodox economics: Evolutionary thinking not only has a presence in the history of economics, but has also undergone a recent revival in which the distinctiveness of a social evolutionary process has been emphasized. This seems to call for a new concept of culture and method of interpretation.

The single chapter Part IV, 'Toward a Culturally Informed Economics,' concludes the book by taking stock of the current state and future direction of economics. Jackson is not very optimistic. The main barriers to cultural methods in economics seem unlikely to change: neoclassical theory, sharply drawn disciplinary boundaries, and a continuing emphasis on mathematical/quantitative techniques. There has been, he allows, a new 'mainstream pluralism' associated with such new fields as experimental economics, behavioral economics, game theory, neuroeconomics, evolutionary economics, and complexity economics, but unfortunately these fields draw almost exclusively upon the natural sciences. Economics seems unable to draw on more qualitative, humanistic fields of investigation, and even the new sub-field of cultural economics appears largely committed to the current goals of the economics profession. Thus, we are left with "enclaves of cultural thought [that have] survived in heterodox economics and in non-economic social sciences", but that have had almost no effect on economic orthodoxy. It is indeed a discouraging picture given the persuasiveness of Jackson's case regarding the need for a role for cultural thinking in economics. Despite this, the book is excellent in setting out and explaining a fundamental critique of economics —one moreover that has been missed by most other current critics of the field. Making this case is an achievement. Hopefully, it will have a greater impact than its author probably expects.

Open Access This article is distributed under the terms of the Creative Commons Attribution Noncommercial License which permits any noncommercial use, distribution, and reproduction in any medium, provided the original author(s) and source are credited. 